\title{
Effect of cattle grazing a species-rich mountain pasture under different stocking rates on the dynamics of diet selection and sward structure
}

\author{
B. Dumont ${ }^{1 \dagger}$, J. P. Garel ${ }^{2}$, C. Ginane ${ }^{1}$, F. Decuq ${ }^{1}$, A. Farruggia ${ }^{1}$, P. Pradel ${ }^{2}$, C. Rigolot ${ }^{1 \mathrm{a}}$ and \\ M. Petit ${ }^{1}$
}

${ }^{1}$ INRA, Unité de Recherches sur les Herbivores, Theix, 63122 Saint-Genès-Champanelle, France, ${ }^{2}$ INRA, Unité Expérimentale de Marcenat, La Borie, 15190 Marcenat, France

(Received 9 January 2007; Accepted 20 April 2007)

\begin{abstract}
Although stocking rate is a key management variable influencing the structure and composition of pastures, only few studies have simultaneously analysed the seasonal patterns of pasture use by cattle, and the adjustments the animals make to maintain intake of a high-quality diet over the grazing season. Therefore, over a 3-year study, we recorded diet selection, plot use and impact of heifers on sward structure and quality under three different stocking rates (0.6, 1.0 and 1.4 livestock units (LU) per ha) in a species-rich mountain pasture of central France. Measurements were made on three occasions between early June and the end of September each year. Overall, heifers selected for bites dominated by legumes or forbs, and against reproductive grass, whatever the stocking rate or season. Selection for tall mixed $(\mathrm{P}<0.05)$, short mixed $(\mathrm{P}<0.05)$ and short pure grass bites $(\mathrm{P}<0.01)$ was more pronounced in plots grazed at the lowest stocking rate. Although heifers' selection for short patches decreased at the end of the season $(\mathrm{P}<0.001)$, they continued to graze previously grazed areas, thus exhibiting a typical 'patch grazing' pattern, with the animals that grazed at the lowest stocking rate tending to better maintain their selection for short patches in September (treatment $\times$ period: $\mathrm{P}=0.078$ ). Neither diet quality nor individual animal performance were affected by the different stocking rate treatments despite high variability in the quantity and quality of herbage offered and differences in diet selection. However, at the $1.4 \mathrm{LU}$ per ha stocking rate, the quantity of forage available per animal at the end of the season, $0.79 \mathrm{t}$ dry matter (DM) per ha of green leaves with the median of sward height at $4.6 \mathrm{~cm}$, approached levels limiting cattle's ability to compensate for the effects of increasing stocking rate. In plots grazed at $0.6 \mathrm{LU}$ per ha, the total herbage biomass remained higher than $3 t \mathrm{DM}$ per ha with more than $30 \%$ of plot area still covered by reproductive grass patches at the end of the grazing season, which in the medium term should affect the botanical composition of these pastures. Sward heterogeneity was high in plots grazed at 1.0 LU per ha, with sufficient herbage availability (1.1 t DM per ha of green leaves) to maintain animal performance, and more than $15 \%$ of plot area was kept at a reproductive stage at the end of the grazing season. Hence, it could represent the optimal balance to satisfy both livestock production and conservation management objectives.
\end{abstract}

Keywords: foraging, global positioning system, grazing intensity, patch grazing, seasons

\section{Introduction}

Because of its effects on habitat structure and biodiversity, grazing represents a major tool for conservation management. Stocking rate is a key management variable influencing the structure and composition of pastures. A decrease in stocking rate is assumed to promote plant species diversity due to the resulting sward heterogeneity

\footnotetext{
${ }^{\dagger}$ E-mail: bertrand.dumont@clermont.inra.fr

a Present address: INRA, UMR Systèmes d'Elevage, Nutrition Animale et Humaine, 35590 Saint-Gilles, France.
}

and reduced disturbance (Grime, 1979). This has been confirmed by surveys of changes in the botanical composition of pastures following a reduction of management intensity or stocking rates (e.g. Kiehl et al., 1996; Hart and Ashby, 1998; Marriott et al., 2004). However, a very low stocking rate is also assumed to reduce plant diversity as a result of competitive exclusion, where the high productivity of some species dominates plant species that cannot compete for light (Grime, 1979). Across Europe, the biodiversity of species-rich semi-natural pastures has been shown to decline under very low stocking rates or after 
cessation of grazing (e.g. Bakker, 1998; Hellstrom et al., 2003; Pavlů et al., 2005).

Hence, it appears that the biodiversity of permanent pastures will decline under both high and very low stocking rates because of the small number of plant species able to tolerate these two management strategies. Although a number of studies have measured the impact of cattle on permanent pastures grazed at different stocking rates (e.g. Hart and Ashby, 1998; Orr et al., 2001; Gillen and Sims, 2006), only a few analysed seasonal patterns in pasture use (Ash and Mclvor, 1998; Kohler et al., 2006) and simultaneously quantified the dietary choices of the animals (Mayer et al., 2003). Yet, many features of the structural heterogeneity of swards are the result of decisions made by grazing herbivores about where and when to place bites (Parsons and Dumont, 2003). At a low stocking rate, cattle grazing leads to the generation of patches differing in forage quality and quantity. This patchiness influences subsequent vegetation with a knock-on effect on animal responses. Cattle have been shown to make a trade-off between intake and diet quality such that their preference for high-quality vegetative regrowths varies according to sward height (Dumont et al., 1995) and grazing season (Ginane et al., 2003; Farruggia et al., 2006). Adler et al. (2001) gave the name 'patch grazing' to the process by which herbivores continue to graze previously grazed areas, a process that leads to an increase in the spatial heterogeneity of the vegetation.

We have observed that under a medium stocking rate, cattle grazing species-rich mountain pasture exploited short patches of better quality less intensively than those grazing in mesotrophic swards characterised by low-to-moderate plant species diversity (Dumont et al., 2007). It was however hypothesised that there would be a stronger patch grazing response (as described by Adler et al., 2001) in species-rich pastures if they were grazed at a very low stocking rate. Therefore, during a 3-year period, we recorded diet selection, plot use and impact of grazing on sward structure and quality under three different stocking rates in a species-rich mountain pasture of central France. In order to assess the interactions between sward structure and seasonal patterns of diet selection at the different stocking rates, measurements were made on three occasions between early June and the end of September each year. Our aim was not only to describe dietary choices according to stocking rate and season, but also to analyse how cattle make a trade-off between quality and quantity as forage availability decreases. By monitoring animal performance, we were able to assess the efficiency of these behavioural adjustments in maintaining the intake of a high-quality diet.

\section{Material and methods}

Experimental sites and animals

The experiment was conducted in an 80-ha natural mountain pasture in the upland area of central France over three grazing seasons between spring 2002 and autumn 2004. The site had always been extensively managed, resulting in a high botanical diversity. The pasture itself included 170 different plant species, with a majority of oligotrophic species due to the low soil nutrient status. Three stocking rates were compared: a high stocking rate designed to have nearly all the edible biomass consumed at the end of the grazing season; an intermediate stocking rate designed to induce strong structural heterogeneity in the sward; and a low stocking rate designed to quantify the negative effects of competition for light. In the high stocking rate treatment, seven heifers per plot were continuously grazed over the whole grazing season, giving 1.4 livestock units (LU) per ha stocking rate (1 $\mathrm{LU}=600 \mathrm{~kg}$ live weight), while five heifers grazed each plot in the intermediate stocking rate treatment (1.0 LU per ha) and only three heifers grazed each plot in the low stocking rate treatment $(0.6 \mathrm{LU}$ per ha). Nine 3.6-ha experimental plots were created within this pasture, so that each stocking rate treatment could be replicated three times according to a randomised-block design, with some differences in vegetation communities between the blocks. A total of 45 , 18-month-old Charolais heifers were used each year. The animals came from the same farm and had all experienced natural upland grasslands with their mothers at a young age. In winter, they were fed a diet composed of $70 \%$ medium-quality mountain pasture hay and 30\% concentrate $(150 \mathrm{~g}$ crude protein per $\mathrm{kg}$ dry matter (DM)). During the experimental grazing periods, the animals were not given concentrate. Behavioural observations and sward measurements were made in each plot at three periods during the grazing season (25 May to 15 October): in spring (early June) before flowering of major sward components, in summer (end of July) when sward heterogeneity was expected to be at a maximum and in autumn (end of September) when cumulative treatment effects were expected to be at a maximum.

\section{Sward measurements}

In each of the three measurement periods, sward height was measured at 500 random points per plot, and the botanical family (grass, legumes or forbs) and vegetation stage (vegetative, reproductive or dead) were recorded at the first place where a stick contacted the undisturbed sward surface. At each point, it was also recorded whether the plants present at ground level below the sampling point were grazed or not. These last data, after being averaged over the whole plot, were taken as a cumulative measure of the impact of the animals from the start of the grazing season. To further estimate sward heterogeneity, we recorded sward height at $10 \mathrm{~cm}$ intervals along a 50 -m-long permanent transect in the middle of each plot. Each point was considered to be either short or tall according to whether its height was lower or higher than $7 \mathrm{~cm}$. A patch was then defined as an uninterrupted series of either short or tall recordings. This allowed us to calculate the average number of patches per linear metre; the higher this value, the more heterogeneous the sward. 
Herbage biomass was determined by cutting five $0.5 \mathrm{~m}^{2}$ $(10 \mathrm{~cm} \times 5 \mathrm{~m}$ long) strips to ground level in each experimental plot at three-week intervals. A further four $0.09 \mathrm{~m}^{2}$ $(30 \times 30 \mathrm{~cm})$ quadrats were cut to ground level in each plot every month, and subsamples were sorted into green leaves, green stems and dead material, and dried at $85^{\circ} \mathrm{C}$ in order to estimate the sward's morphological composition. The quality of herbage consumed was evaluated using hand-simulated bite samples taken at monthly intervals throughout the grazing season. Four 100-g fresh herbage samples per plot and sampling date were therefore collected by cutting the top half of the extended sward, as this broadly corresponds to what cattle select (Farruggia et al., 2006). At each date, two of the samples were taken from short patches (lower than $7 \mathrm{~cm}$ ) and the two others from tall patches (higher than $7 \mathrm{~cm}$ regardless of vegetation stage). Samples were dried at $60^{\circ} \mathrm{C}$ for $48 \mathrm{~h}$ and analysed for nitrogen content (LECO combustion method (Northern Analytical Laboratory Inc., Merrimack, NH, USA); Sweeney and Rexroad, 1987), fibre content (neutral detergent fibre, NDF: Van Soest and Wine, 1967) and pepsin-cellulase solubility (Aufrère and MichaletDoreau, 1983) as a measure of organic matter digestibility (OMD).

\section{Animal measurements}

Dietary choices were measured by scan sampling at 5-min intervals of the activity of three animals within each group, with one observation day per plot (i.e. three per treatment) at each period. Animals were observed from dawn to dusk to account for diurnal variations in dietary preferences (Rutter et al., 2004). An animal was considered to be grazing when it was biting, chewing or swallowing grass, or when it was walking with its muzzle close to the sward. For each animal recorded as grazing, the observer moved as close to the animal as possible without disturbing it in order to record one selected bite. Observers decided beforehand which bite to record once they were close enough to the animal (e.g. the fifth one), in order to avoid bias due to picking the bites that were most clearly visible. This required the animals to be trained to accept the close proximity of an observer during grazing.

Bite types (Table 1) were broadly defined according to their botanical composition (grass, legume or forbs), height (short or tall defined as likely to be a limiting factor to instantaneous intake rate or not, i.e. lower or higher than $7 \mathrm{~cm}$ ) and vegetation stage (vegetative, reproductive or dead). Between scans, additional measurements (bite rate and step rate for $1 \mathrm{~min}$ ) were made throughout the day to obtain more information on animal selectivity during grazing bouts. A step was defined as a movement of one front leg. Following on from the definition of grazing as outlined above, these recordings were interrupted if the animal made at least three consecutive steps with its head up or stood head-up without chewing grass for more than $3 \mathrm{~s}$. A minimum of 15 daily recordings was targeted for each animal. The ratio of bite rate to step rate gives an indication of animals' selectivity; the lower this ratio, the more selective the animal (Lazo and Soriguer, 1993).

Faecal nitrogen concentration, which was used as an overall indicator of diet digestibility, was measured using the LECO combustion method (Sweeney and Rexroad, 1987). Samples were collected from the rectum every month for each focal animal. Animals were weighed every month and given a body condition score (Petit and Agabriel, 1993), ranging from 1 (very thin) to 5 (very fat).

ETHOSYS collars (Scheibe et al., 1998) were used to estimate the daily grazing time, as direct observation of the animals was not a feasible option for estimating nocturnal grazing activity. All the animals were therefore recorded over a complete 24-h period, once between the end of June and mid July, i.e. between the first two main measurement periods when sward was both abundant and of high quality, and once again between the end of September and mid October when herbage quantity and quality had declined. The sum of all 'head down' values of the ETHOSYS collars was taken as an estimate of grazing duration. Global positioning system telemetry collars were used with differential correction (Schlecht et al., 2004) to monitor animal location on the same days. This allowed us to calculate both distance walked daily and the mean inter-individual distance during grazing bouts. For this second variable, we only considered locations of animals spending at least $1 \mathrm{~min}$ 'head down' during the 5-min activity count interval of the ETHOSYS recordings.

\section{Diet selection}

Diet selection, defined as the proportion of a sward (bite) type in the diet relative to its proportion in the plot, was quantified by calculating selectivity indices $\left(S_{i}\right)$ for each sward component using Jacobs' (1974) modification of Ivlev's electivity index:

$$
\mathrm{S}_{i}=\left(c_{i}-a_{i}\right) /\left(c_{i}+a_{i}-2 c_{i} a_{i}\right),
$$

where $c_{i}$ is the proportion (between 0 and 1 ) of component $i$ in the diet and $a_{i}$ is the proportion (between 0 and 1) of component $i$ in the plot. To estimate $a_{i}$, we recorded sward characteristics at $10-\mathrm{cm}$ intervals along the $50-\mathrm{m}$-long permanent transect in the middle of each plot, with two recordings made at each point, i.e. vegetation at first contact and vegetation dominant at ground level. This procedure was preferred to the random stick measurements as two recordings are needed at each point in order to distinguish between pure and mixed potential bites, as described in Table 1. These data were averaged to estimate the relative abundance of each bite type in the sward. For each bite type $\left(c_{i}\right)$, data for individual animals were first aggregated per day and per plot and then linked to the relative abundance of this bite type in the sward.

$S_{i}$ varies from -1 (never used) to +1 (exclusively used), with negative and positive values indicating avoidance and preference, respectively, and 0 indicating that a sward component is used in proportion to its availability. Jacobs' index was chosen for its low sensitivity to variations in the 
Table 1 The different bite types recorded, and the rules used to map transect data to estimates of the bite types available to the animals at that point

\begin{tabular}{|c|c|c|}
\hline Bite types & Bite characteristics & Available bite type (estimated from transect data) \\
\hline Repro. G & Dominated by green grass stems and ears & $\begin{array}{l}\text { (Sward higher than } 11 \mathrm{~cm} \text { with grass stem or grass flower at the upper contact) } \\
\text { or (Grass stem or grass flower recorded at both the upper and the lower } \\
\text { contacts, whatever the point height) or (Grass stem or grass flower recorded at } \\
\text { the upper contact, and legume stem, legume flower, forb stem or forb flower } \\
\text { recorded at the lower contact, whatever the point height) }\end{array}$ \\
\hline TPG & $\begin{array}{l}\text { More than } 90 \% \text { vegetative green grasses } \\
\text { higher than } 7 \mathrm{~cm} \text {, i.e. not limiting IIR }\end{array}$ & $\begin{array}{l}\text { (Sward height higher than } 7 \mathrm{~cm} \text { with grass leaf at both the upper and lower } \\
\text { contacts) or (Sward height higher than } 7 \mathrm{~cm} \text { with grass leaf at the upper contact, } \\
\text { and grass stem, grass flower or grass dead at the lower contact) or (Sward } \\
\text { height between } 7 \text { and } 11 \mathrm{~cm} \text { with grass stem, grass flower or grass dead at the } \\
\text { upper contact and grass leaf at the lower contact) }\end{array}$ \\
\hline TMG & $\begin{array}{l}\text { Higher than } 7 \mathrm{~cm} \text {, i.e. not limiting IIR, } \\
\text { contains some legumes or forbs but } \\
\text { dominated by green } \\
\text { vegetative grasses }\end{array}$ & $\begin{array}{l}\text { (Sward height higher than } 7 \mathrm{~cm} \text { with grass leaf at the upper contact and legume } \\
\text { leaf, forb leaf, legume stem, forb stem, legume flower or forb flower at the lower } \\
\text { contact) or (Sward height between } 7 \text { and } 11 \mathrm{~cm} \text { with grass stem, grass flower or } \\
\text { grass dead at the upper contact and legume leaf or forb leaf at the lower } \\
\text { contact) }\end{array}$ \\
\hline SPG & $\begin{array}{l}\text { More than } 90 \% \text { green vegetative grasses } \\
\text { lower than } 7 \mathrm{~cm} \text {, i.e. limiting IIR }\end{array}$ & $\begin{array}{l}\text { (Sward height lower than } 7 \mathrm{~cm} \text { with grass leaf at both the upper and lower } \\
\text { contacts) or (Sward height lower than } 7 \mathrm{~cm} \text { with grass leaf at the upper contact, } \\
\text { and grass stem, grass flower or grass dead at the lower contact) or (Sward } \\
\text { height lower than } 7 \mathrm{~cm} \text { with grass stem, grass flower or grass dead at the upper } \\
\text { contact and grass leaf at the lower contact) }\end{array}$ \\
\hline SMG & $\begin{array}{l}\text { Lower than } 7 \mathrm{~cm} \text {, i.e. limiting IIR, contains } \\
\text { some legumes or forbs but dominated by } \\
\text { green vegetative grasses }\end{array}$ & $\begin{array}{l}\text { (Sward height lower than } 7 \mathrm{~cm} \text { with grass leaf at the upper contact and legume } \\
\text { leaf, forb leaf, legume stem, forb stem, legume flower or forb flower at the lower } \\
\text { contact) or (Sward height lower than } 7 \mathrm{~cm} \text { with grass stem, grass flower or grass } \\
\text { dead at the upper contact and legume leaf or forb leaf at the lower contact) }\end{array}$ \\
\hline L & Dominated by legumes & $\begin{array}{l}\text { Legume leaf, legume stem or legume flower at the upper contact, whatever the } \\
\text { contact height }\end{array}$ \\
\hline $\mathrm{F}$ & Dominated by forbs & $\begin{array}{l}\text { (Forb leaf spp. at the upper contact, whatever the height) or (Forb stem at the } \\
\text { upper contact whatever the height and forb leaf or forb stem at the lower } \\
\text { contact) }\end{array}$ \\
\hline DG & Dominated by DGs & $\begin{array}{l}\text { (Sward height higher than } 11 \mathrm{~cm} \text { with grass dead at the upper contact) or (Grass } \\
\text { dead at the upper contact and grass stem, grass flower, grass dead, legume dead } \\
\text { or forb dead at the lower contact) or (Sward height lower than } 11 \mathrm{~cm} \text { with grass } \\
\text { stem or grass flower at the upper contact and grass dead, legume dead or forb } \\
\text { dead at the lower contact) }\end{array}$ \\
\hline DF & Dominated by DFs & $\begin{array}{l}\text { (Forb dead at the upper contact) or (Forb stem at the upper contact and forb } \\
\text { dead at the lower contact) }\end{array}$ \\
\hline
\end{tabular}

Repro. $\mathrm{G}=$ reproductive grass; $\mathrm{TPG}=$ tall pure grass; $\mathrm{TMG}=$ tall mixed grass; $\mathrm{SPG}=$ short pure grass; $\mathrm{SMG}=$ short mixed grass; $\mathrm{L}=$ legume; $\mathrm{F}=$ forb; $D G=$ dead grass; $D F=$ dead forb; IIR = instantaneous intake rate.

relative abundance of plant components, thus making it possible to rank both abundant and rare plant components according to their acceptability to the animals. Jacobs' selection indices were also calculated for four synthetic patch types. Bites made on both reproductive and dead grass were combined into a single type. Tall pure grass was defined as outlined in Table 1. Tall mixed patches were defined as the sum of tall mixed grass bites with half of the bites made on forbs. Short patches were defined as the sum of short pure grass, short mixed grass and legume bites with half of the bites made on forbs.

\section{Statistical analyses}

Data were analysed using the PROC Mixed procedure of the Statistical Analysis Systems Institute (SAS software package, 1999) for repeated measurements in order to account for observations made in the same plots over three successive periods and three successive years (Littell et al., 1998). Plot was taken as the statistical unit. Jacobs' indices, ingestive behaviour, herbage biomass, structure and quality, and animal performance measurements were analysed in a model including the main effects of treatment, block, year and period, and the interactions treatment $\times$ block, treatment $\times$ year, treatment $\times$ period and period $\times$ year. Differences between treatments were investigated using the Tukey correction for multiple comparisons. Significance of selection for $\left(S_{i}>0\right)$ or against $\left(S_{i}<0\right)$ each vegetation item was determined by comparing the Jacobs' index results to zero using a Student's $t$-test.

We used the same model to assess the effects of treatment, period and the interaction treatment $\times$ period on the proportion of plot area grazed by the animals, estimated from random stick measurements. A Student's $t$-test for 
paired data was then used to carry out season-based comparisons between the proportion of plot area grazed by groups of three or five heifers with $3 / 7$ or $5 / 7$ of the proportion grazed by groups of seven heifers. Finally, we used the Proc Reg procedure of the SAS software package (1999) to investigate correlations between daily grazing time, distance walked daily or mean inter-individual distance during grazing bouts, and herbage biomass or herbage green leaf mass. This last variable made it possible to combine the quality and quantity of herbage available to the animals.

\section{Results}

Herbage biomass and quality, sward structure

Despite strong annual variations $(P<0.001)$, total herbage biomass was systematically higher $(P<0.05)$ in plots grazed at a low stocking rate over the grazing season (Figure 1a). Herbage biomass was also higher in plots grazed at an intermediate compared with a high stocking rate from the end of July (Figure 1a). Available biomass was reduced at the end of the grazing season $(P<0.001)$. There was a significant treatment $\times$ period interaction $(P<0.01)$, which results from the stability of herbage biomass over the grazing season in plots grazed at a low stocking rate $(P=0.38)$ whereas it decreased between July and September in plots grazed at an intermediate or a high stocking rate $(P<0.05$; Figure 1a). Similar patterns were observed for green leaf biomass (treatment: $P<0.001$; period: $P<0.001$; treatment $\times$ period: $P<0.05$; Figure $1 b$ ), the only differences being that green leaf biomass also decreased at the end of grazing season in plot grazed at a low stocking rate $(P<0.05)$, and that in September it was similar in plots grazed at an intermediate and at a high stocking rate $(P=0.19)$.

The evolution of sward height followed similar trends (Figure 1C), and this regardless of the year (treatment: $P<0.01$; year: $P=0.24$; treatment $\times$ year: $P=0.96$ ). The median of sward height was lesser in plots grazed at a high stocking rate $(P<0.01)$ compared with the other two treatments, which did not differ $(P=0.24)$. It gradually (a)

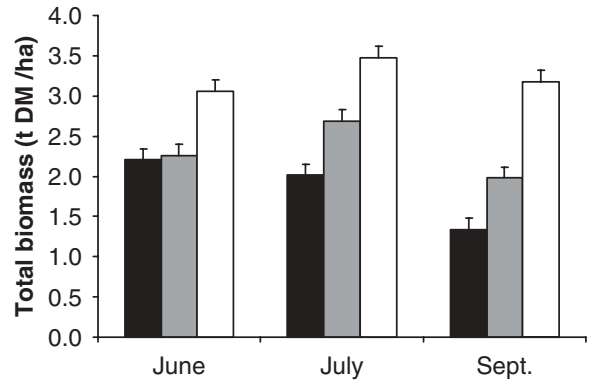

(c)

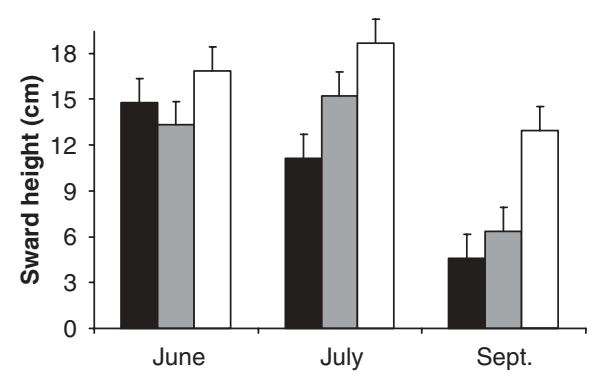

(e)

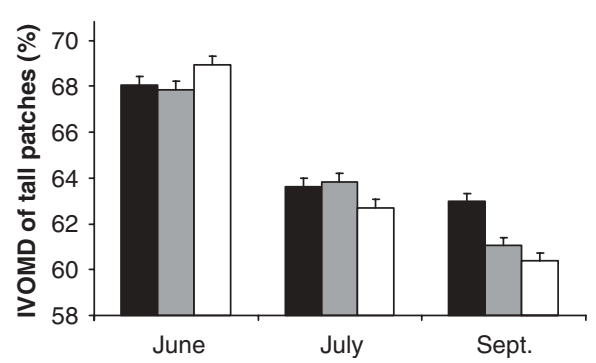

(b)

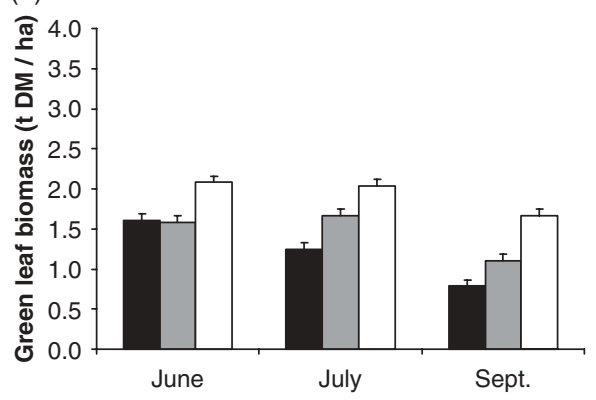

(d)
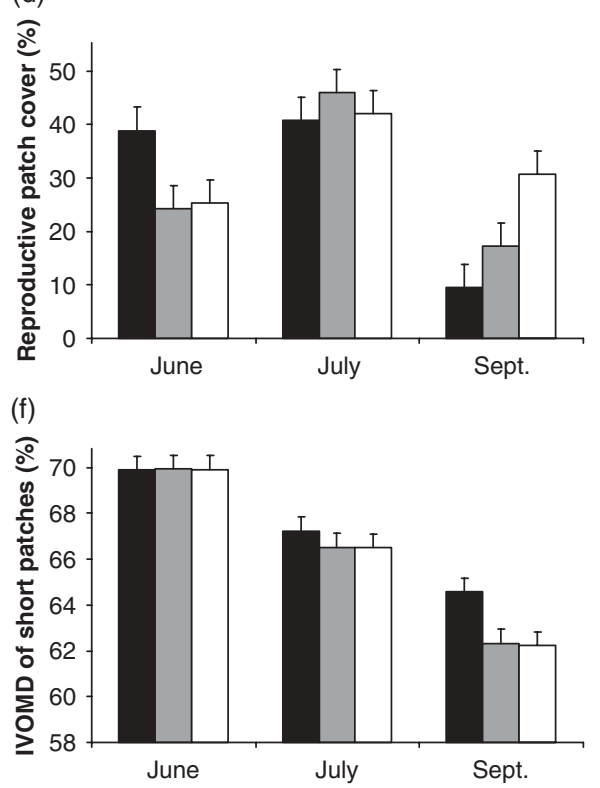

Figure 1 Evolution of herbage biomass and quality over the grazing season in the three stocking rate treatments: (a) total herbage biomass, (b) green leaf biomass, (c) median of sward height, (d) proportion of plot area covered by reproductive patches, (e) digestibility of herbage selected in tall patches and (f) digestibility of herbage selected in short patches. Different shadings are for stocking rate treatments, i.e. black for the high stocking rate, grey for the intermediate stocking rate and open for the low stocking rate. 
decreased over the grazing season in plots grazed at a high stocking rate, whereas in plots grazed at an intermediate or a low stocking rate, it was stable between June and the end of July before decreasing by the end of September (period: $P<0.001$; treatment $\times$ period: $P<0.01$ ). The proportion of plot area covered by reproductive patches (estimated from random stick measurements; Figure 1d) was highest in July and lowest in September (period: $P<0.001$ ), with little variation of this proportion over the grazing season in plots grazed at a low stocking rate ( $P=0.07$ for June $v$. July; $P=0.47$ for July $v$. September) and a consistent ranking of the three stocking rate treatments at the end of the grazing season $(P<0.05$; treatment $\times$ period: $P<0.001$ ).

The quality of selected herbage (estimated from handsimulated bite samples) declined over the grazing season, as indicated by the gradual decrease in the OMD of herbage selected in both the short and tall patches over the grazing season (period: $P<0.001$; Figure 1e and f). The nitrogen content of selected herbage (whatever the patch type) declined between June and July before rising again in September $(28.5,21.0$ and $25.5 \mathrm{~g} \mathrm{~N}$ per $\mathrm{kg} \mathrm{DM}$, respectively; $P<0.001)$. The fibre content of herbage selected within short patches increased at the end of the grazing season: 495, 482 and $513 \mathrm{~g}$ NDF per $\mathrm{kg}$ DM in June, July and September $(P<0.001)$ v. $566 \mathrm{~g}$ NDF per $\mathrm{kg} \mathrm{DM}$ on average for tall patches. Conversely, the quality of selected herbage was only slightly affected by stocking rate, even if the quality of herbage selected in the tall patches was higher in plots grazed at a high stocking rate compared with the two other treatments at the end of the grazing season (treatment: $P<0.05$; treatment $\times$ period: $P<0.001$; Figure 1e). A similar trend was observed for the quality of herbage selected in the short patches (treatment: $P=0.10$; treatment $\times$ period: $P=0.31$; Figure $1 \mathrm{f}$ ). Overall, significant treatment $\times$ period interactions for several herbage biomass and quality variables confirm that the cumulative treatment effects were at a maximum at the end of the grazing season.

The proportion of plot area that was grazed by the animals, i.e. their cumulative impact from the start of the grazing season, increased over the grazing season $(P<0.001)$ as well as with the stocking rate treatments $(P<0.001$; treatment $\times$ period: $P<0.10$; Figure $2 \mathrm{a})$. The proportion of plot area grazed by the animals was directly proportional to the number of animals in the plot in June $(P=0.48$ for 5 v. 7 heifers; $P=0.33$ for 3 v. 7$)$ and July $(P=0.53$ for 5 v. $7 ; P=0.29$ for 3 v. 7). In September, animals grazing at a low or intermediate stocking rate had exploited proportionally more area than those grazing at the high stocking rate $(P<0.001)$.

Sward heterogeneity, estimated from the calculation of the average number of patches per linear metre (Figure $2 b$ ), was lesser in plots grazed at a low stocking rate $(P<0.01)$, and increased over the grazing season $(P<0.001)$ whatever the stocking rate treatment (treatment $\times$ period: $P=0.69)$.
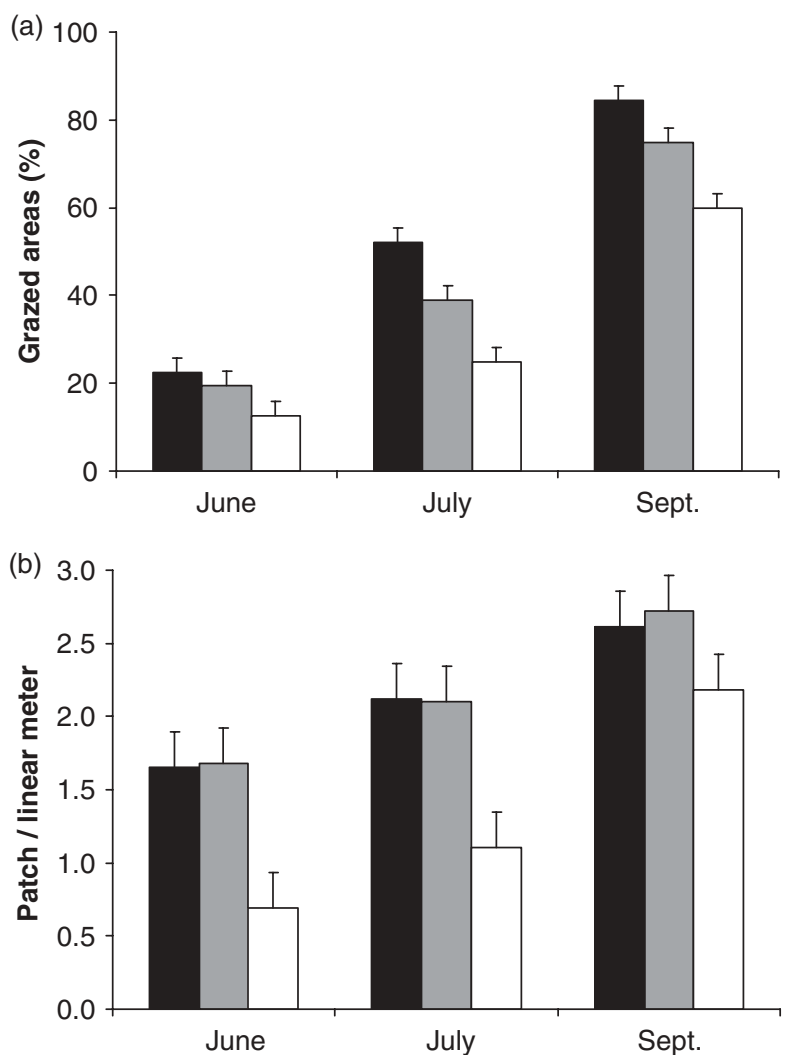

Figure 2 Plot use by the animals according to stocking rate and season: (a) proportion of plot area grazed by the animals, i.e. the cumulative impact of the animals from the start of the grazing season and (b) sward heterogeneity, estimated from the calculation of the average number of patches lower or higher than $7 \mathrm{~cm}$ per linear metre. Different shadings are for stocking rate treatments, i.e. black for the high stocking rate, grey for the intermediate stocking rate and open for the low stocking rate.

\section{Diet selection and foraging behaviour}

Overall, heifers selected for bites dominated by legumes or forbs, and against reproductive grass, dead grass and dead forbs, whatever the stocking rate or season (Table 2). Over the whole grazing season, heifers increased their selection for tall grass patches (either pure or mixed; $P<0.001$; Figure 3) and decreased their selection for short grass patches $(P<0.001)$, even though short mixed grass bites were still preferentially selected in September (Table 2). While selection for tall pure grass bites was unaffected by stocking rate, that for tall mixed $(P<0.05)$, short mixed $(P<0.05)$ and short pure grass bites $(P<0.01)$ was more pronounced in plots grazed at a low stocking rate (Table 2). Consequently, with all short vegetation items taken together, selection for these short patches decreased over the grazing season $(P<0.001$; Figure 3$)$, but the animals grazing at the lowest stocking rate tended to better maintain their selection for short patches in September (treatment $\times$ period: $P=0.078$; Figure 3 ). In addition, selection against reproductive grass tended to be less pronounced at the high stocking rate $(P=0.10)$ and in September $(P=0.086)$, although the treatment $\times$ period interaction remained non-significant (Table 2; $P=0.44$ for reproductive and dead grass taken together: Figure 3 ). 
Dumont, Garel, Ginane, Decuq, Farruggia, Pradel, Rigolot and Petit

Table 2 Diet selection and foraging behaviour (BR, GT, Dist., SR, B/S and IID) of heifers according to stocking rate and season

\begin{tabular}{|c|c|c|c|c|c|c|c|c|c|c|c|}
\hline & \multicolumn{4}{|c|}{ Stocking rate } & \multirow[b]{2}{*}{ Significance } & \multicolumn{4}{|c|}{ Season } & \multirow{2}{*}{\multicolumn{2}{|c|}{$\begin{array}{c}\text { Stocking } \\
\text { Significance rate } \times \text { season }\end{array}$}} \\
\hline & High & Intermediate & Low & s.e. & & June & July & Sept & s.e. $\subseteq$ & & \\
\hline \multicolumn{12}{|l|}{ Jacobs' indices } \\
\hline Repro. G† & -0.49 & -0.72 & -0.70 & 0.09 & $\mathrm{t}$ & -0.79 & -0.69 & -0.43 & 0.08 & $\mathrm{t}$ & NS \\
\hline $\mathrm{TPG}^{+}$ & +0.12 & +0.08 & +0.12 & 0.04 & NS & $-0.03^{x}$ & $+0.16^{y}$ & $+0.20^{y}$ & 0.04 & $* * *$ & NS \\
\hline $\mathrm{TMG}^{\dagger}$ & $+0.17^{a}$ & $+0.21^{\mathrm{ab}}$ & $+0.32^{\mathrm{b}}$ & 0.04 & * & $-0.19^{x}$ & $+0.48^{y}$ & $+0.42^{y}$ & 0.05 & $* * *$ & * \\
\hline $\mathrm{SPG}^{+}$ & $+0.17^{\mathrm{a}}$ & $+0.12^{a}$ & $+0.42^{\mathrm{b}}$ & 0.06 & ** & $+0.46^{x}$ & $+0.25^{y}$ & $-0.00^{z}$ & 0.05 & $* * *$ & NS \\
\hline $\mathrm{SMG}^{+}$ & $+0.43^{\mathrm{a}}$ & $+0.47^{\mathrm{ab}}$ & $+0.65^{b}$ & 0.06 & * & $+0.65^{x}$ & $+0.57^{x}$ & $+0.33^{y}$ & 0.05 & $* * *$ & NS \\
\hline $\mathrm{L}^{+}$ & +0.51 & +0.30 & +0.30 & 0.12 & NS & $+0.71^{x}$ & $+0.25^{y}$ & $+0.15^{y}$ & 0.10 & $* * *$ & NS \\
\hline $\mathrm{F}^{\dagger}$ & +0.19 & +0.21 & +0.16 & 0.08 & NS & +0.18 & +0.14 & +0.23 & 0.06 & NS & NS \\
\hline $\mathrm{DG}^{+}$ & -0.82 & -0.84 & -0.89 & 0.04 & NS & -0.85 & -0.83 & -0.87 & 0.05 & NS & NS \\
\hline $\mathrm{DF}^{\dagger}$ & -0.89 & -0.93 & -0.82 & 0.18 & NS & $-0.68^{x}$ & $-0.98^{y}$ & $-0.98^{y}$ & 0.11 & ** & * \\
\hline Faecal N (g/kg DM) & 24.5 & 24.8 & 25.1 & 0.2 & NS & $29.3^{x}$ & $23.5^{y}$ & $21.7^{z}$ & 0.3 & $* * *$ & NS \\
\hline \multicolumn{12}{|l|}{ Foraging behaviour } \\
\hline BR (per min) & $56.7^{\mathrm{a}}$ & $54.5^{a}$ & $50.7^{\mathrm{b}}$ & 0.9 & ** & $51.2^{x}$ & $51.6^{\mathrm{x}}$ & $59.2^{y}$ & 0.8 & $* * *$ & NS \\
\hline GT (min) & $507^{\mathrm{a}}$ & $499^{a b}$ & $480^{b}$ & 6 & * & $468^{x}$ & & $523^{y}$ & 8 & ** & NS \\
\hline Dist. (m/day) & 4670 & 4410 & 4140 & 250 & NS & $4730^{x}$ & & $4090^{y}$ & 170 & $* *$ & $t$ \\
\hline SR (per min) & 6.5 & 6.6 & 6.7 & 0.2 & NS & $7.2^{\mathrm{x}}$ & $6.6^{y}$ & $5.9^{2}$ & 0.2 & $* * *$ & NS \\
\hline $\mathrm{B} / \mathrm{S}$ & $9.2^{\mathrm{a}}$ & $8.5^{\mathrm{ab}}$ & $7.7^{b}$ & 0.2 & $* *$ & $7.2^{x}$ & $7.9^{y}$ & $10.4^{z}$ & 0.2 & $* * *$ & $* *$ \\
\hline IID (m) & 22.9 & 22.8 & 19.6 & 3.4 & NS & $18.2^{x}$ & & $25.3^{y}$ & 2.1 & $* * *$ & NS \\
\hline
\end{tabular}

$\mathrm{BR}=$ biting rate; $\mathrm{GT}=$ daily grazing time; Dist. = distance walked daily; $\mathrm{SR}=$ step rate; $\mathrm{B} / \mathrm{S}=$ bite per step; $\mathrm{IID}=$ inter-individual distance during grazing bouts; Repro. $G=$ reproductive grass; $T P G=$ tall pure grass; $T M G=$ tall mixed grass; $S P G=$ short pure grass; $S M G=$ short mixed grass; $L=$ legume; $F=$ forb; $\mathrm{DG}=$ dead grass; $\mathrm{DF}=$ dead forb; $\mathrm{DM}=$ dry matter; $\mathrm{NS}=$ not significant; $\mathrm{t}=P<0.10$.

$a, b$ Values within line with different superscript are significantly different at $P<0.05$.

$x_{1}, \mathrm{z}, \mathrm{V}$ Values within line with different superscript are significantly different at $P<0.05$.

${ }^{*} P<0.05,{ }^{* *} P<0.01,{ }^{* * *} P<0.001$.

${ }^{\dagger}$ Bite types are defined in Table 1. Bold characters indicate for items selected for and italics indicate items avoided.

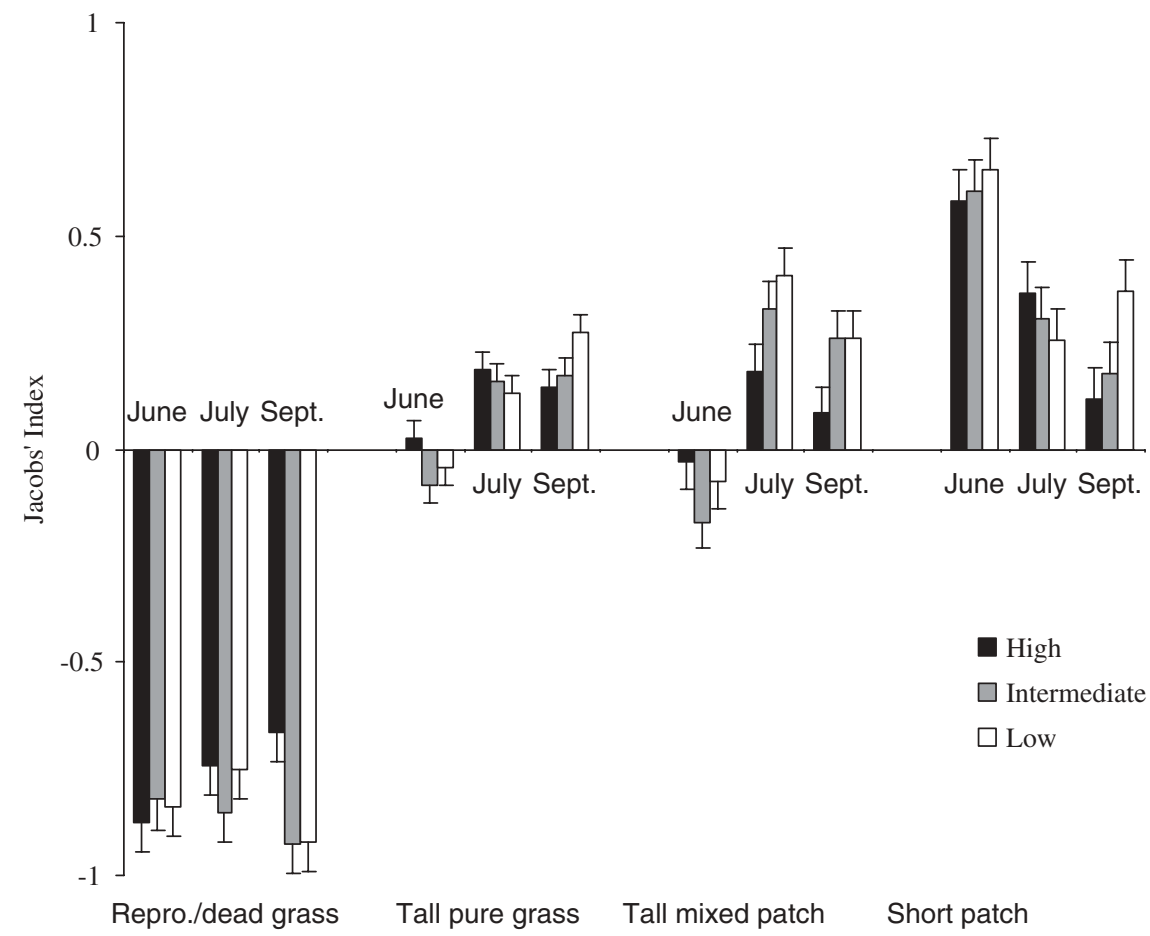

Figure 3 Selection for or against reproductive/dead grass, tall pure grass, tall mixed and short patches according to stocking rate and season. 
In line with these bite selection measurements and with measurements made on the chemical composition of selected herbage, the nitrogen concentration of faeces, which was used as a synthetic index of diet quality, decreased over the grazing season $(P<0.001$; Table 2$)$. There was no other significant effect of the stocking rate treatments $(P=0.33)$, and no treatment $\times$ period interaction $(P=0.99)$.

Mean bite rate increased with increasing stocking rate $(P<0.01$; Table 2), and was also higher in September compared with June and July $(P<0.001)$. Daily grazing time was affected by both stocking rate $(P<0.05)$ and season $(P<0.01)$, without any treatment $\times$ season interaction (Table 2). There was a negative correlation between herbage biomass (HM in t DM per ha) and daily grazing time (GT in min), with $\mathrm{GT}=-18.3 \mathrm{HM}+548 ; r^{2}=0.22$; $P<0.01$, although green leaf allowance (GLM in tDM per ha) proved an even better predictor of daily grazing time:

$$
\mathrm{GT}=-30.6 \mathrm{GLM}+553 ; r^{2}=0.34 ; P=0.001 \text {. }
$$

The distance walked daily by the animals was independent of stocking rate ( $P=0.55$; Table 2). On average, animals walked longer distances in June-July than in September $(P=0.01)$. This late-season decrease in distance walked by the animals was only observed at the two higher stocking rates, i.e. $+0.15 \mathrm{v}$. -1.16 and $-0.92 \mathrm{~km} /$ day for the low, intermediate and high stocking rates, respectively (treatment $\times$ period: $P=0.058$ ). Step rate during a grazing bout also decreased over the grazing season $(P<0.001$; Table 2). Together with the increase in biting rate, this resulted in an increase in the number of bites per step in September $(P<0.001)$, which was more pronounced in plots grazed at a high stocking rate, i.e. 9.0, 10.1 and 12.0 bites per step for the low, intermediate and high stocking rates, respectively (treatment $\times$ period: $P<0.01$ ).

Stocking rate (and consequently group size) had no effect on mean inter-individual distance (IID in $\mathrm{m}$ ) during a grazing bout $(P=0.79)$. IID increased at the end of the grazing season $(P<0.001$; treatment $\times$ period: $P=0.45)$, in line with the negative correlation between herbage biomass (HM in t DM per ha) and IID, with IID $=-3.17 \mathrm{HM}+$ 30.89; $r^{2}=0.21 ; P<0.01$. Again, green leaf allowance (GLM in t DM per ha) proved an even better predictor of IID:

$$
\mathrm{IID}=-4.90 \mathrm{GLM}+31.01 ; r^{2}=0.27 ; P=0.001 \text {. }
$$

\section{Animal performance}

Average daily live-weight gain (LWG) of the animals declined between June and the end of July, before increasing again by the end of September (period: $P<0.001$; Figure 4a). Conversely, LWG was not affected by the different stocking rate treatments $(P=0.24$; treatment $\times$ period: $P=0.36$ ). Body condition scores gradually increased between June and the end of September (period: $P<0.001$; Figure $4 \mathrm{~b}$ ), independent of the stocking rate treatments (treatment: $P=0.84$; treatment $\times$ period: $P=0.57)$.
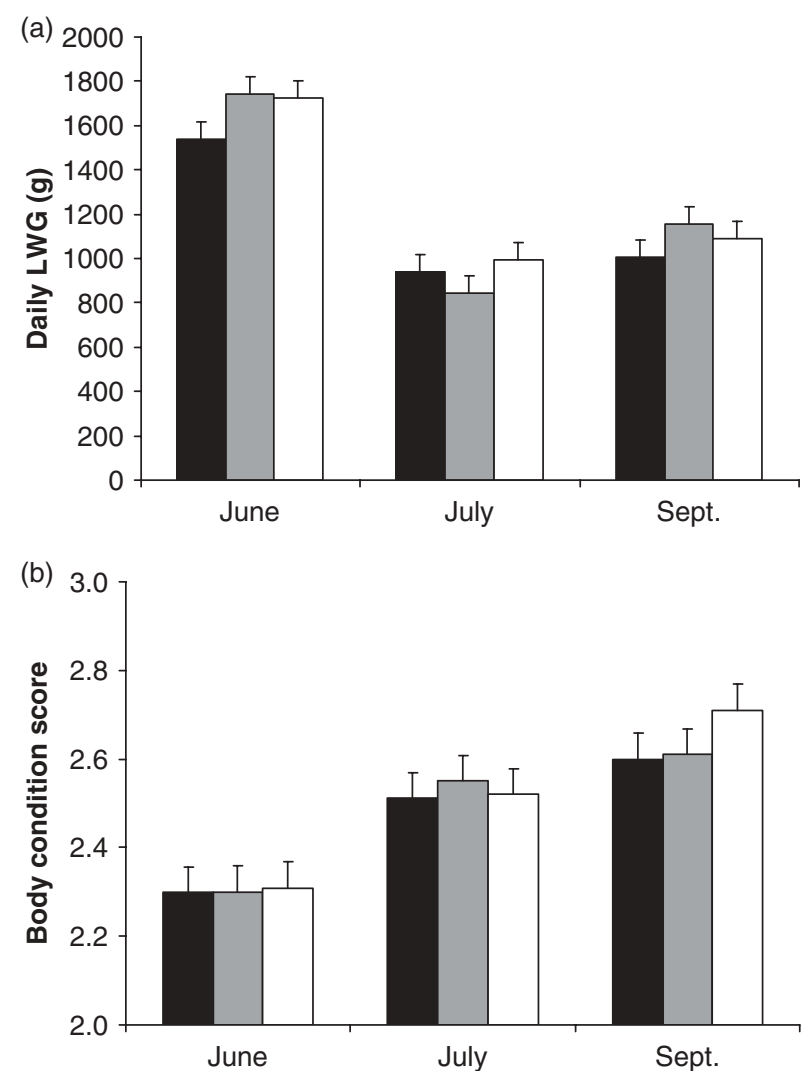

Figure 4 Animal performance according to stocking rate and season: (a) live-weight gain and (b) body condition score. Different shadings are for stocking rate treatments, i.e. black for the high stocking rate, grey for the intermediate stocking rate and open for the low stocking rate.

\section{Discussion}

Heifers exhibited very typical selection patterns, selecting for legumes and forbs and against reproductive grass and dead material (Rutter et al., 2004; Dumont et al., 1995 and 2007), whatever the stocking rate or season. They also selected short vegetative patches rather than tall ones due to the higher nutritive value of these short patches (see also McNaughton, 1984). The heifers selected short patches right from the start of the grazing season, regardless of the stocking rate. Although this selection for short patches decreased at the end of the season, the animals continued to graze previously grazed areas, i.e. they showed patch grazing as described by Adler et al. (2001). Ewes have also been observed to select short areas from the end of spring and continue to avoid tall areas at the end of the grazing season in a cocksfoot plot grazed at a low stocking rate (Garcia et al., 2004). In a direct comparison that took place in four mesotrophic or semi-natural grasslands across western Europe, Dumont et al. (2007) reported that cattle and sheep showed more-pronounced selection of wellgrazed areas of better quality in productive mesotrophic vegetations than in semi-natural grasslands with a strong fine-scale heterogeneity and a relatively high nutritive value. However, the authors hypothesised that a more pronounced patch grazing response could occur in 
semi-natural grasslands if they were grazed at a lower stocking rate, which is confirmed by our observation that heifers grazing at the lowest stocking rate tended to better maintain their selection for short patches at the end of the season.

The greater exploitation of well-grazed areas of better quality is expected to reinforce the spatial heterogeneity of vegetation over the grazing season. The proportion of plot area that was grazed by the animals, i.e. their cumulative impact from the start of the grazing season, was directly proportional to stocking rate until July, whereas at the end of the season animals grazing at a low or intermediate stocking rate had exploited proportionally more area than those grazing at a high stocking rate. Thus, although cattle grazing at the lowest stocking rate displayed patch grazing until the end of the grazing season, they thus also markedly extended the proportion of plot area kept at a vegetative stage. This 'upkeep' of pastures at the end of the grazing season could contribute to maintaining the sward's agronomic potential in plots grazed at a low stocking rate while limiting the negative effects on biodiversity exerted by the competition for light. However, total herbage biomass remained higher than $3 \mathrm{t}$ DM per ha over the whole grazing season. More than $30 \%$ of plot area were still covered by reproductive grass patches at the end of the grazing season, and the balance between short and tall areas (i.e. lower or higher than $7 \mathrm{~cm}$ ) remained lesser compared with that in plots grazed at a higher stocking rate, which in the medium term should affect the botanical composition of these pastures.

In plots grazed at the intermediate stocking rate, the selection for tall mixed and for short patches that was maintained until the end of the grazing season suggests that animals kept the possibility of grazing areas with high fodder potential (Kohler et al., 2006). Total herbage biomass averaged $2 \mathrm{t}$ DM per ha at the end of the grazing season including 1.1 t DM per ha of green leaves, which is sufficient to maintain animal performance. Sward heterogeneity was systematically higher than that in plots grazed at a low stocking rate, with more than $15 \%$ of plot area kept at a reproductive stage at the end of the grazing season. This patch mosaic is expected to favour vegetation and insect diversity by providing resources for species characteristic of short as well as tall vegetation, with reduced disturbance for plant species that are less tolerant to grazing (Grime, 1979; Marriott et al., 2004), and increased habitat quality for insects requiring buffered microclimates (Wallis De Vries et al., 2007). Hence, it could represent the optimal balance to satisfy both livestock production and conservation management objectives.

In plots grazed at the high stocking rate, the proportion of grazed patches reached an average of $85 \%$ of plot area at the end of the grazing season. The balance between short and tall areas was similar to that in the plots grazed at an intermediate stocking rate, but herbage availability was strongly reduced at the end of the grazing season with only $1.34 \mathrm{t} \mathrm{DM}$ per ha of total herbage biomass (including
$0.79 \mathrm{t}$ DM per ha of green leaves) and the median of sward height at $4.6 \mathrm{~cm}$. In September, less than $10 \%$ of plot area was kept at a vegetative stage. As these plots became depleted, the heifers were forced to use less-preferred vegetation, resulting in a more balanced selection pattern (see also Kohler et al., 2006). They were less reluctant to feed on reproductive grass, but the animals' consumption of tall patches could have been limited by the presence of faeces or unpalatable plant species such as thistles (see also Cid and Brizuela, 1998). Furthermore, overgrazing of short patches could in the long-term result in divergent vegetation dynamics compared with plots grazed at a lower stocking rate.

When faced with constraints in the quality and availability of pastures, grazing herbivores show great behavioural flexibility to compensate for this restricted forage availability (lason et al., 1999; Garcia et al., 2003). Late in the season, heifers increased their daily grazing time and inter-individual distance while grazing, which are classical adjustments by which grazing herbivores respond to a decrease in forage availability (Arnold and Dudzinski, 1978). Dumont and Boissy (2000) have observed that in sheep grazed in groups of up to seven individuals, a conflict arose between the motivation to express a food preference and to maintain social contact, animals shifting between the two attractants as the size of their group varied. Here, heifers grazed in groups between three and seven animals did not alter their inter-individual distance, which suggests that compared with sheep the grazing behaviour of cattle could be less influenced by their social context.

Heifers grazing at a high stocking rate increased not only their daily grazing time but also their biting rate and number of bites per step. The increase in biting rate is the mechanistic reaction by which herbivores respond to a decrease in sward surface height (Arnold and Dudzinski, 1978). Heifers grazing at a high stocking rate benefited from a slightly higher quality of selected herbage in both the short and tall patches at the end of the grazing season. In September, they also more strongly increased their biteto-step ratio compared with the animals grazing at lower stocking rates. This indicates that their initial tactic of research was gradually abandoned in favour of a 'lawnmower'-type tactic (see Roguet et al., 1998 and Garcia et al., 2003, for similar conclusions on grazing sheep). Hence, both their daily distance covered and average number of steps per minute of grazing were reduced at the end of the season.

In plots grazed at the two lower stocking rates, the heifers maintained their intake of a high-quality diet by selecting tall mixed patches and previously grazed short areas. Daily distance walked and bite-to-step ratio remained relatively constant over the grazing season for animals grazing at a low stocking rate, which suggests they kept on exploring the plots in autumn. This is consistent with previous observations that extensively grazed sheep (Garcia et al., 2003) and cattle (Kohler et al., 2006) maintain their selective effort late in the season after the proportion of 
reproductive and senescent material in the sward had increased. Consistently, neither diet quality nor individual animal performance was affected by being grazed at a low stocking rate. This observation that quality of cattle diet is quite independent of stocking rate has already been reported under a wide range of sward conditions (e.g. Ortega et al., 1997; Schlegel et al., 2000; Mayer et al., 2003). In addition, our results confirm the flexibility in utilisation of species-rich mountain pastures, in which cattle can adjust their grazing behaviour to maintain intake of a high-quality diet despite high variability in the quantity and quality of herbage offered and differences in diet selection. However, at the $1.4 \mathrm{LU}$ per ha stocking rate, the quantity of forage available at the end of the season could approach levels limiting cattle's ability to compensate for the effects of increasing stocking rate. Conversely, a stocking rate of $1.0 \mathrm{LU}$ per ha would represent the optimal balance to satisfy both livestock production and conservation management objectives in species-rich mountain pastures.

\section{Acknowledgements}

The research team received European Union financial support under project QLK5-2001-00130 FoRBIOBEN. We are grateful to the staff of the INRA farm at Marcenat for taking care of the animals, and to C. Cirié, T. Renard and B. Ricci for their help with field measurements. We thank J. M. Ballet, M. Dudilieu, J. Jamot, A. Le Morvan, J. Pourrat and C. Ravel for making the herbage quality measurements and sorting the herbage subsamples.

\section{References}

Adler PB, Raff DA and Lauenroth WK 2001. The effect of grazing on the spatial heterogeneity of vegetation. Oecologia 128, 465-479.

Arnold GW and Dudzinski ML 1978. Ethology of free-ranging domestic animals. Elsevier Scientific Publishing, Amsterdam, The Netherlands.

Ash AJ and Mclvor JG 1998. How season of grazing and herbivore selectivity influence monsoon tall-grass communities of northern Australia. Journal of Vegetation Science 9, 123-132.

Aufrère J and Michalet-Doreau B 1983. In vivo digestibility and prediction of digestibility of some by-products. EEC seminar EUR 8918 EN on feeding value of by-products and their use by beef cattle. Melle-Gontrode, Belgium, pp. 25-35.

Bakker JP 1998. The impact of grazing on plant communities. In Grazing and conservation management (ed. MF Wallis De Vries, JP Bakker and SE Van Wieren), pp. 137-184. Kluwer Academic Publishers, Dordrecht, The Netherlands.

Cid MS and Brizuela MA 1998. Heterogeneity in tall fescue pastures created and sustained by cattle grazing. Journal of Range Management 51, 644-649. Dumont B and Boissy A 2000. Grazing behaviour of sheep in a situation of conflict between feeding and social motivations. Behavioural Processes 49, 131-138.

Dumont B, Petit M and D'hour P 1995. Choice of sheep and cattle between vegetative and reproductive cocksfoot patches. Applied Animal Behaviour Science 43, 1-15.

Dumont B, Rook AJ, Coran C and Röver KU 2007. Effects of livestock breed and grazing intensity on biodiversity and production in grazing systems. 2. Diet selection. Grass and Forage Science 62, 159-171.
Farruggia A, Dumont B, Dhour P, Egal D and Petit M 2006. Diet selection of dry and lactating beef cows grazing extensive pastures in late autumn. Grass and Forage Science 61, 347-353.

Garcia F, Carrère P, Soussana JF and Baumont R 2003. The ability of sheep at different stocking rates to maintain the quality and quantity of their diet during the grazing season. Journal of Agricultural Science, Cambridge 140, 113-124.

Garcia F, Carrère P, Decuq F and Baumont R 2004. Mapping grazing activity and sward variability improves our understanding of plant-animal interaction in heterogeneous grasslands. In Land use systems in grassland dominated regions. Grassland Science in Europe (ed. A Lüscher, B Jeangros, W Kessler, 0 Huguenin, M Lobsiger, N Millar and D Suter), vol. 9, pp. 763-765. British Grassland Society, Reading, UK.

Gillen RL and Sims PL 2006. Stocking rate and weather impacts on sand sagebrush and grasses: a 20-year record. Rangeland Ecology and Management $59,145-152$

Ginane C, Petit M and Dhour P 2003. How do grazing heifers choose between maturing reproductive and tall or short vegetative swards? Applied Animal Behaviour Science 83, 15-27.

Grime JP 1979. Plant strategies and vegetation processes. Wiley, Chichester, UK.

Hart RH and Ashby MM 1998. Grazing intensities, vegetation, and heifer gains: 55 years on shortgrass. Journal of Range Management 51, 392-398.

Hellstrom K, Huhta AP, Rautio P, Tuomi J, Oksanen J and Kari L 2003. Use of sheep grazing in the restoration of semi-natural meadows in northern Finland. Applied Vegetation Science 6, 45-52.

lason GR, Mantecon AR, Sim DA, Gonzalez J, Foreman E, Bermudez FF and Elston DA 1999. Can grazing sheep compensate for a daily foraging time constraint? Journal of Animal Ecology 68, 87-93.

Jacobs J 1974. Quantitative measurements of food selection. A modification of the forage ratio and Ivlev's electivity index. Oecologia 14, 413-417.

Kiehl K, Eischeid I, Gettner S and Walter J 1996. Impact of different sheep grazing intensities on salt marsh vegetation in northern Germany. Journal of Vegetation Science 7, 99-106.

Kohler F, Gillet F, Reust S, Wagner HH, Gadallah F, Gobat JM and Buttler A 2006. Spatial and seasonal patterns of cattle habitat use in a mountain wooded pasture. Landscape Ecology 21, 281-295.

Lazo A and Soriguer RC 1993. Size-biased foraging behaviour in feral cattle. Applied Animal Behaviour Science 36, 99-110.

Littell RC, Henry PR and Ammerman CB 1998. Statistical analyses of repeated measures data using SAS procedures. Journal of Animal Science 76, $1216-1231$.

Marriott CA, Fothergill M, Jeangros B, Scotton M and Louault F 2004. Longterm impacts of extensification of grassland management on biodiversity and productivity in upland areas. A review. Agronomie 24, 447-462.

Mayer AC, Stöckli V, Huovinen C, Konold W, Estermann BL and Kreuzer M 2003. Herbage selection by cattle on sub-alpine wood pastures. Forest Ecology and Management 181, 39-50.

McNaughton SJ 1984. Grazing lawns: animals in herds, plant form, and coevolution. The American Naturalist 124, 863-886.

Orr DM, Burrows WH, Hendricksen RE, Clem RL, Rutherford MT, Conway MJ, Myles DJ, Back PV and Paton CJ 2001. Pasture yield and composition changes in a Central Queensland black speargrass (Heteropogon contortus) pasture in relation to grazing management options. Australian Journal of Experimental Agriculture 41, 477-485.

Ortega IM, Soltero-Gardea S, Drawe DL and Bryant FC 1997. Evaluating grazing strategies for cattle: nutrition of cattle and deer. Journal of Range Management 50, 631-637.

Parsons AJ and Dumont B 2003. Spatial heterogeneity and grazing processes. Animal Research 52, 161-179.

Pavlù V, Hejcman M, Pavlù L, Gaisler J, Nežerková P and Guerovich Andaluz M 2005. Vegetation changes after cessation of grazing management in the Jizerské Mountains (Czech Republic). Annales Botanici Fennici 42, 343-349.

Petit M and Agabriel J 1993. Etat corporel des vaches allaitantes Charolaises : signification, utilisation pratique et relations avec la reproduction. INRA Productions Animales 6, 311-318.

Roguet C, Prache S and Petit M 1998. Feeding station behaviour of ewes in response to forage availability and sward phenological stage. Applied Animal Behaviour Science 56, 187-201. 


\section{Dumont, Garel, Ginane, Decuq, Farruggia, Pradel, Rigolot and Petit}

Rutter SM, Orr RJ, Yarrow NH and Champion RA 2004. Dietary preference of dairy cows grazing ryegrass and white clover. Journal of Dairy Science 87, 1317-1324.

Scheibe KM, Schleusner T, Berger A, Eichhorn K, Langbein J, Dal Zotto $L$ and Streich WJ 1998. ETHOSYS ${ }^{\circledR}$ - new system for recording and analysis of behaviour of free-ranging domestic animals and wildlife. Applied Animal Behaviour Science 55, 195-211.

Schlecht E, Hülsebusch C, Mahler F and Becker K 2004. The use of differentially corrected global positioning system to monitor activities of cattle at pasture. Applied Animal Behaviour Science 85, 185-202.

Schlegel ML, Wachenheim CJ, Benson ME, Ames NK and Rust SR 2000. Grazing methods and stocking rates for direct-seeded alfalfa pastures: II. Pasture quality and diet selection. Journal of Animal Science 78, 2202-2208.
Statistical Analysis Systems Institute 1999. SAS/STAT user's guide, version 8. SAS Institute Inc., Cary, NC.

Sweeney RA and Rexroad PR 1987. Comparison of LECO FP-228 "nitrogen determinator" with AOAC copper catalyst Kjeldahl method for crude protein. Journal of the Association of Official Analytical Chemists 70, 1028-1030.

Van Soest PJ and Wine RH 1967. Use of detergents in the analysis of fibrous feeds. IV. Determination of plant cell-wall constituents. Journal of the Association of Official Analytical Chemists 50, 50-55.

Wallis De Vries MF, Parkinson AE, Dulphy JP, Sayer M and Diana E 2007. Effects of livestock breed and grazing intensity on biodiversity and production in grazing systems. 4. Effects on animal diversity. Grass and Forage Science 62 , 185-197. 